\title{
Needs and Trends of Rain Water Harvesting in Sri Lanka
}

\author{
${ }^{1}$ S. Sayanthan, ${ }^{2}$ Thushyanthi Mikunthan, ${ }^{3}$ Nadarajah kannan, ${ }^{4}$ Mahalingam Prabhaharan, \\ ${ }^{5}$ N.Thaneswaran, \\ 1, 2, 3, 4, 5 Kaalikovilady, Karaveddy east, Jaffna, Sri Lanka
}

*Corresponding Author: S. Sayanthan, Kaalikovilady, Karaveddy east, Jaffna, Sri Lanka

\begin{abstract}
Water being one of the world's basic resources and the most important element for lives to survive. But, because of several water related issues and population growth Sri Lanka is in a negative track in terms of water sustainability. Hence the country needs to adopt an ideal process which must leads the country towards a steady state in the case of available water. The answer should be Rain water harvesting. Even though the country has been practicing rain water harvesting for many centuries, the system was unable to satisfy the domestic needs in systemic and scientific ways until the introduction of Community Water Supply \& Sanitation Project in 1996. After this initiation rain water harvesting projects were carried out by many other government and non-government organizations. Now the country has far better rain water harvesting systems. But it is essential to ensure well established rainwater harvesting systems all over the country which will make us to step in to a water rich era.
\end{abstract}

Keywords: Surface water; Ground water; Water management; Rain water harvesting; Rain water treatment; Rain water quality.

\begin{abstract}
Abbreviations: RWH - Rain Water Harvesting RWHS - Rain Water Harvesting System; ADRA - Adventist Development \& Relief Agency Sri Lanka ; Asiaonlus -ASIAONLUS; BLIA - Buddha's Light International Association; CI - Care International; CWSSP - Community Water Supply \& Sanitation Project; EC - Ekamuthu Cultivators ; GTZ -GTZ; HKLM - HKL Menike;IOM - International Organization For Migration; ITDG Intermediate Technology Development Group;KOPBMO - Kala Oya River Basin Management Office; LRVVHF Lanka Rain Water Harvesting Forum; NCC - National Christian Council; NGOWSSDS - GO Water Supply And Sanitation Decade Service; NWSDB - National Water Supply \& Drainage Board; ORDE - Organization For Resource Development And Environment; OXFAM - OXFAM; PALM - PALM Foundation; Plan - Plan Sri Lanka; PRDA - People's Rural Development Association; Sarvodaya - Lanka Jathika Sarvodaya Shramadana Sangamaya; SDA - Southern Development Authority; USIP - Urban Settlement Improvement Project; VW - World Vision;PVC Polyvinyl Chloride; LRWHF- Lanka Rain Water Harvesting Forum
\end{abstract}

\section{INTRODUCTION}

Man has fought to sustain oneself even in deserts for thousands of years, and succeeded on it by the skilful management of vital and scarce resource; water. Obviously water is the cardinal resource, prevailing to ensure the existence of all living beings and proposing a part of larger ecosystem (UN-Water, 2015). Even more, availability of sufficient water is an index of development of a country (Weerarathna et al., 2009). Therefore the sustainability of water should be ensured in order to corroborate the existence of the earth. The availability of water was predictable before the interference of human in the natural water cycle. But after the human intrusions such as deforestation, wetland drainage and other means of pollution, the balanced and favourable sequence started to collapse and it has led the world towards water related issues (Charles, 2000). The ultimate reaction will be more dangerous and it is estimated that one third of the world population is going to face hardships because of water scarcity.

Within the globe, Asia is in the worst condition in the case of water availability because it consists $60 \%$ from the world total population but the availability of the water is only $36 \%$ from the total available water (UNESCO, 2003). When we specify the Sri Lanka, available data portrays Sri Lanka as a country with either low scarcity or no water scarcity (Tanuja Ariyananda, 2010). Even though some dry zone areas during the draught season are in the courtyards to fight for the water. Statistically water supply of the country covers $78 \%$ of population in terms of drinking water. Within this, 35\% only provided with structured piped water others are expected to depend on other water resources such as bore well and springs (Ariyananda and Aheeyer, 2011). Due to population growth, limitation of water resources and climatic change, the availability of water is getting diminished and the demand for the water is getting swelled (Ariyananda, 2007). Therefore gradually we are getting in to a scenario of water scarcity and we need to think about tenable ways to strengthen the sustainability of available water. 
So many technologies and strategies are there to strengthen the water sector of a country such as $3 \mathrm{R}$ process (Reuse, Reduce and Recycle), sea water purification, rain water harvesting and so on. But before a country proceeds a suitable way it should ensure the feasibility of such system in the country. Mainly the resource availability, technology availability and cost benefit. As far as Sri Lanka is concerned technically, it is not far big and the availability of investments also low. Therefore it is not possible to establish large number of advanced water purification systems in order to cover the whole country. Hence consideration of low cost and minimal technology is essential during the progress of water sector of the country.

Rain water is the primary water source and the annual rain fall of Sri Lanka is around 1800mm through bi model rainfall. But more than $70 \%$ of total rainfall escapes to the sea (Weerarathna et al., 2009) so saving such water for human consumption could be an ideal and sustainable way to get rid from the issues related to water. Such way of water depository action is called as "rain water harvesting". This system is obviously a low cost system and it can be made easily with the help of family labours. Even though Sri Lanka had a long history in rain water harvesting, such efforts had been lessened with the introduction of pipe supply and protected wells. Now the government and other supporting NGO's are awaken to replenish the rain water harvesting sector, specifically the sector has started to work with more agility with the formation of rain water harvesting forum in 1996(Weerarathna et al., 2009). No wonder, due to the immense hard work of this institutional combination the country is going forward, towards surged condition in terms of available water.

\section{WATER SECTOR IN SRI LANKA}

\subsection{Water Availability in Sri Lanka}

It was estimated that total actual renewable water resources of Sri Lanka is around 52,800 million cubic meter per year and per capita availability was 2,555 cubic meter In year 2009 (Irrigation in Southern and Eastern Asia in Figures, 2012). Available water resources can be divided as ground water and Surface water (Case study: Sri Lanka Sri Lanka National Water Development Report, 2006).

As far as ground water of Sri Lanka is concerned, there are six types of aquifers such as shallow unconfined karstic aquifers, deep confined sandstone and Miocene limestone aquifers, shallow quaternary unconfined coastal sand aquifers, alluvial aquifers of variable depth, shallow regolith aquifers of the hard rock region, Confined or semi confined lateritic aquifers (Villholth and Rajasooriyar, 2009). From the above mentioned aquifers ground water have been extracted in different type of wells and total estimated potential of Ground water of Sri Lanka is around 7800million cubic meter per year(Case study : Sri Lanka Sri Lanka National Water Development Report, 2006).

In the case of surface water the river systems prevails are drastically contributing to surface water and it is around 45,800 million cubic meters. There are around 103 distinct river basins covers $90 \%$ of island (Irrigation in Southern and Eastern Asia in Figures, 2012). But the variation in available water quantity will exist across the river. Building enough reservoirs and diverting the water to the dry zone will remunerate the inequality. Even though two different types of water sources exist, major part is always occupied by rain water and it is the sole agent recharging the above sources (Tanuja Ariyananda, 2010). But the rain fall is not uniform throughout the country and it is the reason behind undulating water tables and uneven quantity of water in reservoirs across the country.

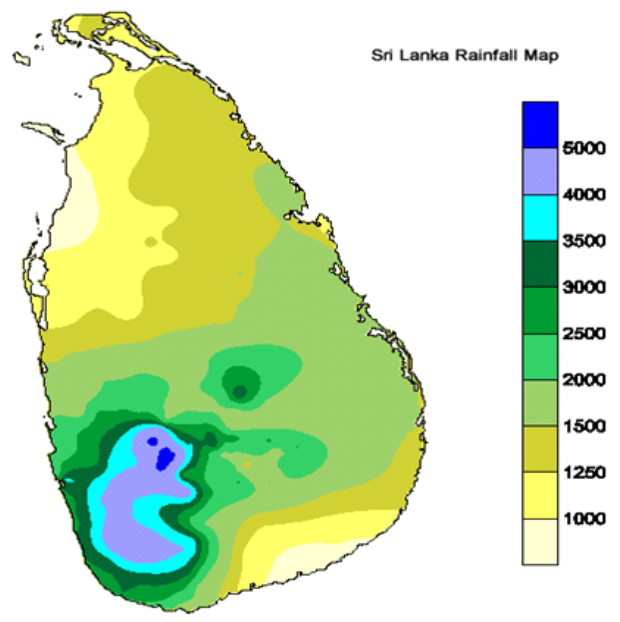

Figure1. Zones of Rainfall in Sri Lanka (" 'Climate of Sri Lanka, ,” n.d.) 
On the basis of rainfall pattern Country can be primarily divided as Dry zone and wet zone. Former one is getting around $1440 \mathrm{~mm}$ annual rain fall and latter is prosperous with $2350 \mathrm{~mm}$ annual rain fall (Weerarathna et al., 2009). On the whole the annual average rain fall of the country is around 1800 $\mathrm{mm}$ which is equal to 120,000 million cubic meters. Figure 1 shows the variability of rain fall across the country.

\subsection{Water Withdrawal}

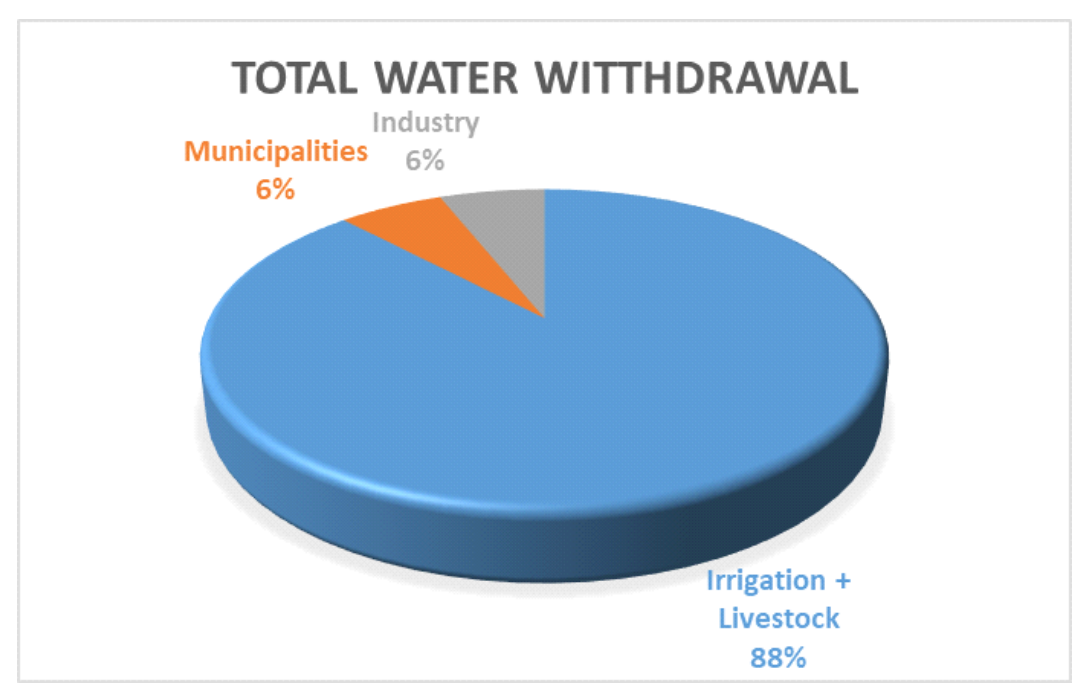

Chart1. (Irrigation in Southern and Eastern Asia in Figures, 2012)

It was estimated that total water withdrawal in 2005 was 12,950 million m3. Among that 11,314 million cubic meter was utilized for irrigation and livestock, 805 million meter cube for municipal usage and 831 million cubic meter for industrial purposes(Irrigation in Southern and Eastern Asia in Figures, 2012). Chart 1 describes the percentage of water withdrawal by sector. In 2006, ground water usage for domestic water supply in rural areas was $72 \%$ and in urban areas it was $22 \%$ (Sri Lanka socio-economic data 2006, 2006).

Table1. Percentage contribution of ground water and surface water for water supply (Panabokke and Perera, 2005)

\begin{tabular}{|l|l|l|}
\hline District & Supply of surface water resources $\left(10^{3} \mathrm{~m}^{3} / \mathrm{yr}\right)$ & Supply of ground water resources $\left(10^{3} \mathrm{~m}^{3} / \mathrm{yr}\right)$ \\
\hline Ampara & 4,427 & 120 \\
\hline Anuradapura & 6,453 & 1,199 \\
\hline Badulla & 8,111 & 0 \\
\hline Baticaloa & 0 & 529 \\
\hline Colombo & 205,090 & 0 \\
\hline Galle & 9,220 & 360 \\
\hline Gampaha & 17,109 & 1,774 \\
Hambantota & 9,547 & 373 \\
\hline Jaffna & 0 & 76 \\
\hline Kegalle & 5,799 & 0 \\
\hline Kalutara & 10,967 & 203 \\
\hline Kandy & 11,258 & 4,830 \\
\hline Kurunagella & 3,534 & 657 \\
\hline Mannar & 0 & 201 \\
\hline Monaragala & 1,539 & 4 \\
\hline Matale & 4,525 & 261 \\
\hline Matara & 27,802 & 479 \\
\hline Nuweraeliya & 1,541 & 1,643 \\
\hline Pollanaruva & 2,672 & 122 \\
Puttlum & 98 & 3,075 \\
\hline Ratnapura & 7,172 & 0 \\
Trincomale & 520 & 3 \\
\hline Vavuniya & 0 & 283 \\
\hline & 337,385 & 16,192 \\
\hline
\end{tabular}




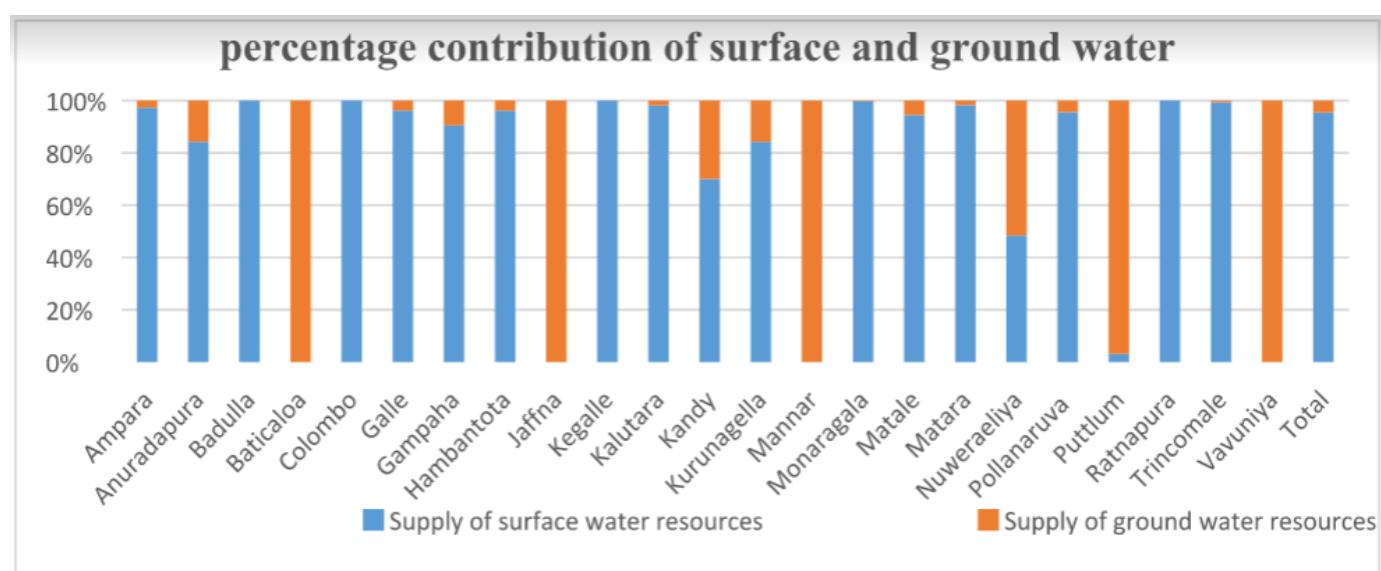

Chart2. percentage contribution of surface and ground water (Panabokke and Perera, 2005)

Table 1 describes quantity supply of two distinct water resources to major cities of Sri Lanka. Here we can spot out that Baticaloa, Jaffna, Mannar and Vavuniya are only rely on ground water, Badulla, Colombo, Kegalle, Ratnapura are only depend on surface water. But being depend on both water resources is far better than being with one. Chart 2 portrays the percentage contribution of ground water and surface water for water supply to the cities of Sri Lanka. It is clear that surface water gives the contribution above $95 \%$ to total water supply.

\subsection{Importance of Rain Water Harvesting}

\subsubsection{Issues Related with the Population Growth}

Sustainable economic development through optimum utilization of its natural resources is the prime objective of Sri Lanka (Dissanayake, n.d.). When we look in to the water resources of Sri Lanka, it is clear that the country is not in a sustainable track because, though the current per capita availability of water is $2400 \mathrm{~m}^{3}$ which is higher than the recommended threshold level of $1700 \mathrm{~m}^{3}$, the country is going to be in a position with per capita availability of $1800 \mathrm{~m}^{3}$ in 2025(Tanuja Ariyananda, 2010). The main reason behind this negative scenario will be the population growth accompanied by water pollution and ecological imbalance.

Chart 3 describes the total population from 2007 to 2016. We can notice that, in Sri Lanka from 2012 to 2016 the total population changes were in an increasing manner. Simultaneously it has been reported that the quantity and quality of the available water of Sri Lanka is getting deteriorated. Therefore this effect should be a result of inter reaction between the population growth and available water. It is no wonder that with the population growth, chances for water pollution and ecological imbalance are high. Therefore it can be concluded that the population growth is the key factor for all water crisis which are going to happen in the country. As mentioned earlier now the population growth of the country is in positive way. Therefore it is essential to ensure water for all.

\subsubsection{Issues Related with the Surface Water}

In the case of Surface water quality improper and inadequate waste disposal are the gate way for water pollution. It has been reported that the lower reaches of Kelani River, Beria Lake and Bolgoda Lake are severely affected by the pollution due to over load of industrial waste and untreated faecal material (UN-Water, 2015). Secondly the use of agro chemicals plays a considerable role in the pollution of surface water. There are some reservoirs under affected condition such as Kothmale, Kandy Lake and Graagory, Nuwara wewa, thissa wewa and many other lakes in Anurathapura. Finally, the salt water intrusion is also a serious issue to maintain a pure water system. It can be observed in Kelani Ganga which is contributing for drinking water supply for Colombo city (UNWater, 2015).

\subsubsection{Issues Related with the Ground Water}

The depletion of ground water is mainly due to encroachment of agro chemicals, over exploitation and salt water intrusion. The former one is very transparent in Jaffna and the nitrate concentration if over $200 \mathrm{mg}$ per litre was reported. Over exploitation and salt water intrusion are prominent in Puttalam, Mannar, Paranthan, Kilinochchi, and Mullaithivu (UN-Water, 2015). Even the availability of 
ground water is low; the demand is improving drastically, especially for urban and rural water supplies, irrigation purposes and for industries. Such rapid exploitation is giving more pressure on ground water (Irrigation in Southern and Eastern Asia in Figures, 2012). These kinds of negative trends of available water of Sri Lanka make us to think about the dry days will be going to make us suffer. So we need to think about an alternate idea instead of stick on the ground water and surface water, definitely the answer should be "Rain Water Harvesting".

\subsubsection{Issues Related with the Rainfall}

Three quarter of Sri Lanka has portioned as dry zone but actually by the amount of rain fall those areas are comparatively better than many European countries. But the issue is all of the rain falls in the 3 months of the north-east Monsoon between October and December (Ariyananda et al., 1995). And the rain often comes in short dramatic bursts causing floods of water even some places can get all their annual amount of rain in a couple of days this will ultimately cause the water loss and leads to a shake in the water cycle . According to the above mentioned issues, as far as Sri Lanka is concerned Hence it is so important to collect as much of this water as possible to avoid scarcity for the rest of the year. As far as Sri Lanka is concerned rain water harvesting is the ideal way to solve the negative impact; water scarcity which comes from the above mentioned issues. This is mainly because the country is facing bimodal rainfall with the appreciable amount of water. But within the total quantity of runoff water $65 \%$ is being escaped to the sea. The amount is $33.4 \mathrm{~km} 3$, if the people are keen enough to store such water it will definitely leads the country towards a sustainable water management tradition and it will ensure the water availability for all the citizens of Sri Lanka. Table 2 shows the Rain fall runoff percentage analysis of Sri Lanka.

\section{RAIN WATER HARVESTING}

\subsection{History of Rain Water Harvesting}

When we look back to the history, it is overt that rain water harvesting is not a novel idea to the world. According to the documents available, people have started to practice this system as early as 4500B.C but the difference from prevailing system is that they have used natural materials while the current scenario is going with the synthetic artificial means to increase the runoff from precipitation (Sivanappan, 2006). The evidence from Negave desert portrays that people have adopted some reasonable engineering techniques in order to form a Rain water harvesting system, starting with clearance of hill side to smoothen the soil in order facilitate the runoff and then they built counter ditches to store the water and ultimately it was allowed to low lying fields to irrigate the crops (Evenari et al., 1971).

When the conditions of some early civilized countries were like as mentioned above in the case of water management, Sri Lanka also not half bad, indeed it has a long resolute history of hydraulic civilization. Several reservoirs, tanks, and irrigation structures were established in 5th century B.C, ideally the dry zone of Sri Lanka was protected from the water scarcity with the establishment of numerous tanks with varying capacity which were assisted the people with sufficient water especially during the drought season(Weerarathna et al., 2009). Other milestone in the history was powered by King Kasyapa by the structures which he made in Sigiriya, a rock fortress; the storage reservoirs, fountains and swimming pool relied on rain water (Ariyananda, 1999). Even though country was enriched with thousands of tanks, some only size specific and contributed much; Minneria tank built by king Mahasena with the coverage of 19000 ha, more over Kalawewa and parakirama samudra are other gigantic tanks which have been contributing for animals rearing, irrigation purposes along with human consumption (Weerarathna et al., 2009).

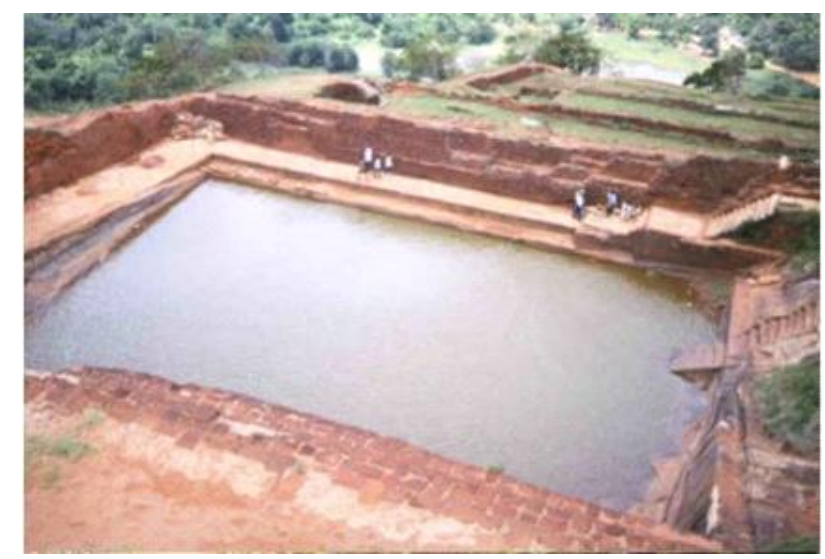

Figure2. Rock Sigiriya ("Rainwater Harvesting," n.d.) 


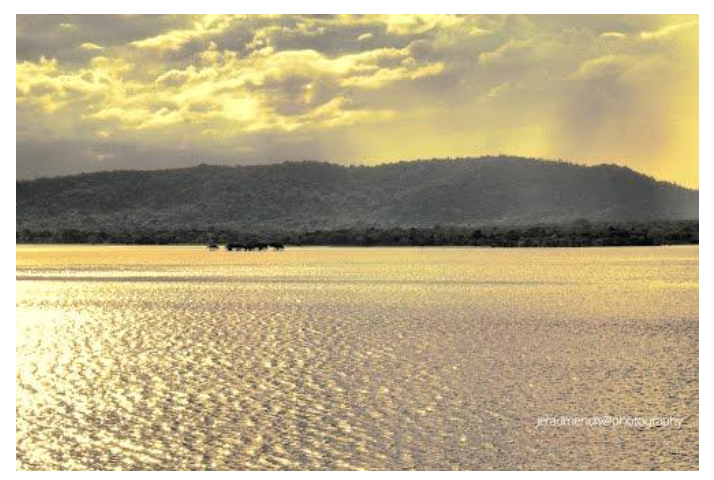

Figure3. Parakrama samudra ("Parakrama Samudrya," n.d.)

Figure 2 shows a reservoir cut into the rock in Sigriya to hold harvested rainwater. Figure 3 shows a view of Parakrama samudra. Finally the famous proclamation of Parakramabahu the great (1153-1186 AD); "let's not allow a single drop of water to flow in to the sea without being used for the benefit of mankind" is a clear evidence how the rulers of Sri Lanka had mentality towards sustainable water management (Ariyananda et al., 2010)

\subsection{Growth and Development of Rain Water Harvesting}

Rain water harvesting is the collection of runoff from a structure or other impervious surfaces to be stored for later usages. The falling rain drops in a surface will be directed by gutters to down spouts channels in to a storage system. This process is being popularized in the world and increasing in demand. In Sri Lanka, as mentioned earlier it has been practiced in from antique time. rather than the tanks and dams built by the kings people from the house hold level also harvested the rain water using Banana leaves, coconut leaves and royal palm leaves instead of gutters which will direct the water in to a pot or any other domestic containers(Weerarathna et al., 2009). But concept of institutional rain water harvesting in households, office, schools and other places where ever possible, is new to Sri Lanka ("What is Rain Water Harvesting?," n.d.).

Under the World Bank sponsored community water supply and sanitation project, large scale household rural rainwater harvesting program was established in Badulla and Matara districts in 1995. Soon after the termination of community water supply and sanitation project several organizations such as Lanka rain water harvesting forum, Southern development authority, Sarvodaya and National water supply and drainage board started to put up the rain water harvesting as a way to supply water to water sort households both in wet and dry zones of Sri Lanka (T Ariyananda, 2010) .Then after only government spot out it as an efficient and effective way of water conservation. Because of such awareness national policy on rain water harvesting and strategies was accepted by the government in 2005 which was recommended by the minister for urban development and water supply and on April 17, 2009 a legislation was enacted which emphasise the importance of rainwater harvesting in certain categories of new buildings in areas under municipal and urban council jurisdiction (Tanuja Ariyananda, 2010). Among the institutions rose to pillar up the rain water harvesting in Sri Lanka, Lanka rain water harvesting forum has been working as a predominant one. This has been started to work at the beginning of 1996 and officially take off its activity from March of 1997 ("What is Rain Water Harvesting?" n.d.).The Lanka rain water harvesting forum has been working very actively to spread out the rain water harvesting system all over the districts for last two decades via Training awareness programs, Researches and demonstration programs combined with some nongovernment organizations (Ariyananda, 1999).

Presently there are four forms of rain water harvesting practices are existing currently

1. Traditional Rainwater Harvesting Practice - These systems such as using banana leaves, coconut leaves and collect rain water directly without any structures like catchment are almost non-existent or very rarely practiced with other more conventional practices. The prime reason for using these methods at present is to increase the water availability at household level.

2. Conventional Rainwater Harvesting Practice - Most of the houses in rural areas of Sri Lanka are bi segmented one is kitchen other one is main living house. The roofs of both segments taper towards one side, forming a sufficiently large catchment area to harvest rainwater and between the edges of the roofs there will be an improved gutter made by tin sheet which will carry the harvested rain water 
to an open tank strait below the gutter terminal. And the size of the tanks will be varies from 300 to 1000 litre

3. Informal Rainwater Harvesting Practice this is the most commonly available method in Sri Lanka. Specifically in rural areas this is the method under usage. The most common employs the 200 litre barrels that are freely available rather than these drums are the other types of container. The water collected from the harvesting will be used for immediate needs. Usually informal rainwater collection makes an important contribution to household water security during the rainy season.

4. Institutional Rainwater Harvesting Practice Institutional Rainwater Harvesting Practice is a recent practice started with the Community Water Supply and Sanitation Project (CWSSP) and has been supported by NGOs and Provincial authorities. Under institutional rainwater harvesting, two basic systems each with $5 \mathrm{~m}^{3}$ storage were introduced. These systems were used to combine with other water resources and support for improved household water security by providing a "water reserve" ("Domestic Roof Water Harvesting in the Humid Tropics Drwh to Achieve Water Security under Stress Conditions," 2000). At present there are around 30000 domestic rain water harvesting systems with varying capacity are available. Most of rain water harvesting systems is available in rural areas. Table 3 express the number of available rain water tanks and the respective contributors.

\subsection{Present Rain Water Harvesting Techniques}

In 2007 government legalized the adoption of rain water in all new building in urban areas. This urban development amendment has created awareness about rain water harvesting among people. It consist guide lines for the constructors and minimum quantity of water needs to be save by each category of building such as residential, commercial, industrial and institutional(THE GAZETTE OF THE DEMOCRATIC SOCIALIST REPUBLIC OF SRI LANKA, 2007).

Even though the peoples of Sri Lanka have been using several techniques to achieve required quantity of water they all can be categorized in to two groups

\section{Run off harvesting}

\section{Roof top harvesting}

Runoff Harvesting - Gardens, driveways, landscapes, open fields, parks, roads and pavements and other open areas of the environment are the catchment area to harvest the rain water runoff. Specifically this method is prospective for low rain fall areas. As this method is covering large area as catchment the water collected from this method is more suitable for agriculture. Even though the urban area is very low or nil in cultivation the saved water can be directed to pits in order to re charge the ground water ("RWH Technology," n.d.).

Rooftop Harvesting - Roof tops of houses, schools, offices, flats and factories will be the catchment areas which are impervious. This type of system is mainly focus on water for domestic use, so the storing water should be clean and good. In quality in order to maintain quality and estimated quantity the system needs to be adopting several components ("RWH Technology," n.d.)

\subsubsection{Catchment}

This is the basic component which will collect the water and drains in to the storage system. In Sri Lanka mostly the roofing materials and other water runoff surfaces have been used for this purposes but in the case of drinking water purpose water should be harvested from roofs but the roofs should not be thatched roofs, asphalt and materials made by led ("RWH Technology," n.d.). In order to find the quantity of water that can be harvested by certain catchment, first the total area of the catchment should be estimated. Then the rain fall data from nearby station is required finally the runoff coefficient should be taken in to the account (Weerarathna et al., 2009).

\subsubsection{Delivery System}

This system is the weakest system in terms of support and stability. If it is properly fitted $90 \%$ or more harvested water can be drained in to the storage system (Weerarathna et al., 2009). This system consist gutters, pipes, and filters ("RWH Technology, n.d.). Gutters and pipes are used to transport the water in to the storage system these can be made by PVC, metal sheets or bamboo but in areas with high rain fall in Sri Lanka, rain water may shoots over the gutters and leads to rain water loss in order to prevent that flash guards need to be used(UN-Water, 2015). 


\subsubsection{Storage}

Table2. Cost for a Ferro cement storage tank (Aheeyar, 2009)

\begin{tabular}{|c|c|c|c|c|}
\hline \multicolumn{5}{|l|}{ Cost } \\
\hline Types & $\mathbf{5 ~ m}^{\mathbf{3}}$ & $7 \mathbf{~ m}^{3}$ & $8 \mathbf{~ m}^{3}$ & $10 \mathrm{~m}^{3}$ \\
\hline Skilled labour & 4500 & 5400 & 5580 & 8000 \\
\hline Unskilled labour & 5000 & 5500 & 6000 & 10000 \\
\hline Transport of materials & 2500 & 2500 & 2500 & 2500 \\
\hline Miscellaneous & 1427.5 & 1500 & 1595 & 1750 \\
\hline Pipes, first flush, gutters, other accessories and fixing charges & $\begin{array}{c}5000 \\
4273300\end{array}$ & $\begin{array}{c}5000 \\
468195\end{array}$ & $\begin{array}{c}5000 \\
503945\end{array}$ & $\begin{array}{c}5000 \\
626205\end{array}$ \\
\hline
\end{tabular}

This part covers more fraction of money within the total budget. Table 5 reveals the cost of production for 5, 7, 8 and 10 cubic meter Ferro cement tank in 2009. Therefore it is essential to focus more on the construction (Weerarathna et al., 2009). According to the position of tank construction it can be categorized as above ground tank, underground tank, and partial underground tank. Among the above forms of tanks bricks have been used to construct underground tank other two have been built by fero cement (Tanuja Ariyananda, 2010). Within the different kinds of tanks, surface tanks are costly but have high durability (Weerarathna et al., 2009). Moreover, according to the shapes also the tanks can be differentiated as cylindrical rectangular hexagonal and square tanks ("RWH Technology," n.d.).

Generally the size of such tanks varies from 5-30 cubic meter for domestic system and 50-100 cubic meter for community system (Weerarathna et al., 2009). Figure 6, 7, 8 respectively shows underground tank, partial underground tank and above ground tank.

\subsection{Quality of the Harvested Water}

Rain water is a pure source of water as it directly comes with low or nil contamination (Ariyananda et al., 2010). The water harvested from the well maintained roof top can be used for drinking purpose and other house hold uses but the runoff water can't be used for such purposes it can only be used in agricultural purposes and to recharge the ground water. Practically it is very hard to maintain a roof system to harvest the water for drinking water purpose. The researches done in different districts of Sri Lanka regarding water quality of harvested rain water from well-maintained system, give vivid explanation in most aspects of water quality as follow. The $\mathrm{pH}$ will be high in water from new tanks due to the effect of cement and will recover to the standard after some flushes. Conductivity and turbidity of the rain water is maintained at recommended level of WHO (Tanuja Ariyananda, 2010). More than $40 \%$ of the tested rainwater tanks recorded no Escherichia coli. In more than $55 \%$ of the rainwater tanks, the Escherichia coli levels are less than $10 \mathrm{in} 100 \mathrm{ml}$ of water which is the WHO low risk value (Ariyananda, 2003).

According to the earlier studies only around $10-15 \%$ of total beneficiaries used harvested rain water for drinking purposes because of the presence of leaves, mosquito larvae, insects and rodents and also due unpleasant colour and odour (Ariyabandu, 1999). But because of the technology improvement and awareness among the people, now the maintained quality of the water has gone up hence the percentage of rain water as portable water usage has increased up to $80-90 \%$, this scenario can be ensured by recent study on third ADB-funded water sanitation project (Tanuja Ariyananda, 2010).

\subsection{Rain Water Treatments}

To maintain the quality of water different types of filters are being used. Debris is the visible dirt which affects the quality of water. Mostly this kind of obstacles can be observed during the first rain, in order to avoid such circumstance first flush system has been practiced. There are two types, one is manual and other one is automatic. In manual system a person has to stand and set the pipe away from the storage tank and need to turn it in to the tank after the debris are removed. Automatic system consist a tipping gutter as shown in figure 8 . A bucket is used for collect the first flush, after a certain time it will off balance the tipping gutter because of the weight loss of the bucket due to continuous removal of water to another waste water collection drum. After such removal the rain water will be directed to the tank. ("Rainwater Harvesting," n.d.).

In the case of storage system, it is very much essential to looking for the microbial contamination and other dissolved materials. The purification of the stored water is being carried out by several 
processes such as chlorination, boiling, sand filtration and solar radiation. More over in some wellestablished families and organizations the engagement of reverse osmosis filters for filtering the rain water has been observed.

Chlorination happens usually after the separation of water from the tank, because chlorine may reacts with the deposited organic matters in the tank (Adam and Bubnis, 1995). Slow sand filter is a cheap method to purify the stored water. The usage of bio films inside the filters contributes much for the filtration rather than physical process. Inside the filters the coarse particle used to be in the upper part and fine soils in the lower part. Filtration efficiency relies on the development of thin biological layers (Helmreich and Horn, 2010). The long time persistence of sand filters will be ensured by the pretreatment of water. And the constant flow rate of water through the filter will ensure the effectiveness of the filters (Fewster et al., 2004). In Sri Lanka, there are some treatment plants which are involved to filter the runoff water through slow sand and pebble matrix filters. Pre-treatment of harvested water with pebble matrix filter before slow sand filters helps to increase the durability of slow sand filters by vast removal of turbidity. Kataragama water treatment plant is a good example for such treatment (Rajapakshe et al., 2010).

In addition to above mentioned technologies usage of membrane filter system can be observed in some institutions and in some households with decent income. These systems remove particles as fine as .001 microns. They can effectively remove Ions and metals, particles microorganisms, pesticides and radio nuclides (Dvorak et al., 2014) but the problem with the membrane filtration is, Regardless of system size, maintenance needs to be carried out regularly.

\section{AdVAntages of Rain Water Harvesting}

With the long term perspective RWH is obviously a good choice compare to other means of water supply in Sri Lanka. Ensured supply of water for households is the most prominent result of RWH in Sri Lanka. Because of the availability of efficient RWH system in households, the per capita usage of water has increased from 28 lire to 43 litre in no-beneficiary households (Ariyabandu, 1999) The results of a research conducted by Kumari in 2008 indicates that in rural RWH process a $5 \mathrm{~m} 3$ tank with roof area of 75 to $100 \mathrm{~m} 2$ can supply 300 litres/day to a house hold (Kumari, 2008). The stored rain water can be used for drinking purpose with minimal or zero post storage sanitation process. More over the usage of harvested water for toilet and washing purposes will support for the improvement in personal health. Furthermore the stored water can be used for agricultural purposes mainly in home garden, the efficiency and effectiveness of such process can be improved by maintain a drip system(Tanuja Ariyananda, 2010). In the in land fresh water fisheries sector water is the limiting factor which can be overcome by a properly constructed big sized RWH tank (Ariyananda et al., 2010) and such large scale storage systems reduce the pressure on drainage systems and efficiently control the floods. Therefore it indirectly reduces the soil erosion also. The RWH system encourages the house hold to engage with mushroom cultivation, poultry, and goat rearing and so on to make them economically strong (Tanuja Ariyananda, 2010). Other major advantage of rain water harvesting is ground water recharge.

Due to the evaporation and extraction ground water will be depleted so the runoff water storage in ponds can be support to make an increment in ground water table by percolation this was confirmed by a study carried out by Shanthi de Silva in 2005. Figure 9 shows the pond used to recharge the ground water in Nikawaretiya during the study(Shanthi, 2005) RWH in urban areas also leading to many advantageous functions, specifically It can be a supplement for pipe water due this the bill for the water can be reduced and also saving energy of pumping from the well. A study was conducted separately within low income group and high income groups of Anurathapura, Kandy and Negambo to find out the reduction in water bill after the contribution of harvested rain water for household usages. Chart 4 clearly explain the percentage of bill reduction in low income group is around 34\% and chart 5 express that bill reduction in high income group is around 60\% (Ariyananda, 2007). Hence this scenario is a clear example for the economic viability of the RWH system.

\section{CONCLUSION AND RECOMMENDATIONS}

Even though Sri Lanka doesn't have any water scarcity except some areas of dry zone during drought season but because of population growth, urbanization and water pollution the country is expected to face water scarcity soon. Hence the people of Sri Lanka need to prepare themselves to overcome this issue, the ideal way of rescue from such water crisis is RWH. RWH is an effective and efficient 
system which has been adopted by Sri Lankan peoples from the ancient time. The potential and possibility for RWH is higher in Sri Lanka because of rhythmic seasonal rainfall with considerable amount. In Sri Lanka time to time RWH system was carried out by different government, and nongovernment sectors. But now Lanka rain water harvesting forum is playing a remarkable role in RWH. The different systems and technology adopted for RWH are fairly good compare to other developing countries. Quality of the harvested rain water from well maintain roof top harvesting system is acceptable for drinking purpose according to the WHO recommendations and it is an ideal alternate for tap water. The harvested runoff water is being used for irrigation and ground water recharge. It has been reported that around $65 \%$ of total runoff escapes in to sea. But the availability of harvesting systems are less it is around 30000 so the government of Sri Lanka needs to enforce a legislation which should leads all the households to be with a RWHS. Incentives, such as tax rebates, should be given to householders to adopt them to RWH. Government should offer special subsidies to the peoples who are engaged with farming activity with the support of rain water. This type of activities will ensure the sustainability of water in Sri Lanka for the upcoming risky days.

\section{REFERENCES}

[1] "Climate Of Sri Lanka" [WWW Document], n.d. URL Meteo.gov.lk. Web. (Accessed 6.15.17).

[2] Adam, L., Bubnis, B., 1995. Minimizing Chlorate Ion Formation in Drinking Water When Hypochlorite Ion Is the Chlorinating Agent [ Project \# 833 ] 13-15.

[3] Ariyabandu, R. de S., 1999. Development of rainwater harvesting for domestic water use in Rural Sri Lanka. Asia. Pac. J. Rural Dev. 9.

[4] Ariyananda, T., 1995. Development of Rainwater Harvesting Projects in Sri Lanka. Civ. Eng. 293-297.

[5] Ariyananda, T., 1999. Rain water harvesting for domestic use in Sri Lanka, in: WEDC CONFERENCE.

[6] Ariyananda, T., 2010. Domestic rainwater harvesting as a water supply option in Sri Lanka. Hydro Nepal J. Water, Energy ... 27-30.

[7] Ariyananda, T., 2010. Promoting Domestic Rain water Harvesting in Sri Lanka. Ariyananda, T., 2007. RAIN WATER HARVESTING FOR URBAN BUILDINGS IN SRI LANKA.

[8] Ariyananda, T., Aheeyer, M., 2011. Effectiveness of Rain Water Harvesting ( RWH ) Systems as a Domestic Water Supply Option.

[9] Ariyananda, T., Wickramasuriya, S.S., Wijeyesekera, D.S., 2010. Rain water harvesting for water efficiency and management 1 13-14. Case study: Sri Lanka Sri Lanka National Water Development Report, 2006.

[10] Ariyananda, T.., 2003. Health risk due to drinking domestic roof water harvested., in: Eleventh IRCSA Conference. Mexico.

[11]Charles, J., 2000. Anthropogenic disturbance of the terrestrial water cycle 50, 753-765.

[12] Dissanayake, I., n.d. WHY SRI LANKA SHOULD CONCENTRATE ON RAINWATER. Domestic Roof Water Harvesting in the Humid Tropics Drwh To Achieve Water Security Under Stress Conditions, 2000.

[13] Dvorak, B.I., 2014. Drinking Water Treatment : Reverse Osmosis.

[14] Evenari, M., Shanan, L., Tadmor, N., 1971. The Negev: The Challenge of a Desert.

[15]Fewster, E., Mol, A., Brandsma, C.W., 2004. The long-term sustainability of household bio-sand filtration 558-561.

[16] Helmreich, B., Horn, H., 2010. opportunities in rainwater harvesting. J. Desalin. 118-124.

[17] Irrigation in Southern and Eastern Asia in Figures, 2012.

[18] Kumari, D.M.C.., 2008. Drought mitigation using rain water harvesting in the dry zone of Sri Lanka. Rainwater Harvesting, n.d.

[19]RAJAPAKSE, J.., SUMANAWEERA, S., GALLEGE, S., THILLAINATHAN, V., 2010. First Full-Scale Trials of Pebble Matrix Filtration, in: International Conference on Environment. Queensland, pp. 1-14.

[20]RWH Technology [WWW Document], n.d. . Lanka rainwater Harvest. forum. URL http://lankarainwater.org/wp/?page_id=1231 (accessed 5.25.17).

[21] Shanthi, de S., 2005. Impact of Artificial Recharging of Groundwater with Rain water: a case Study in Kotewehera of Sri Lanka.

[22] Sivanappan, R.., 2006. Rain Water Harvesting, Conservation and Management Strategies for Urban and Rural Sectors, in: National Seminar on Rainwater Harvesting and Water Management. Nagpur, pp. 1-5.

[23] Sri Lanka socio-economic data 2006, 2006. . Colombo.

[24] THE GAZETTE OF THE DEMOCRATIC SOCIALIST REPUBLIC OF SRI LANKA, 2007. . Sri Lanka. 
[25] UNESCO, 2003. Water for People, Water for Life. World Water Dev. Rep. 36. doi:10.1017/CBO9781107 415324.004

[26] UN-Water, 2015. Water for a sustainable world. doi:10.1016/S1366-7017(02)00004-1

[27] Villholth, K.G., Rajasooriyar, L.D., 2009. Groundwater Resources and Management challenges in Sri Lanka-an Over view. 1-25. doi:10.1007/s11269-009-9510-6

[28] Weerarathna, C.., Weerasinghe, P.., Deva, H., Aheeyar, M.., Jayantha, G., Ajith, P., Neil, P., 2009. Rain Water Harvesting Practitioners Guide for Sri Lanka, 1st ed. Nugegoda.

[29] Weerasinghe, P.A Ariyananda, T.., Weeraratna, C.S., 2005. Rain Water Harvesting for Home Gardens in Dry Zone of Sri Lanka, in: XII IRSCA Conference. New delhi. What is Rain Water Harvesting? [WWW Document], n.d. . Lanka rain water Harvest. forum. URL http://lankarainwater.org/wp/?page_id=1217 (accessed 5.25.17)

Citation: S. Sayanthan et al., "Needs and Trends of Rain Water Harvesting in Sri Lanka", International Journal of Research Studies in Agricultural Sciences, vol. 3, no. 12, p. 42-52, 2017. http://dx.doi.org/ 10.20431/2454-6224.0312005

Copyright: () 2017 Authors. This is an open-access article distributed under the terms of the Creative Commons Attribution License, which permits unrestricted use, distribution, and reproduction in any medium, provided the original author and source are credited. 